\title{
KULTUROWE CZY POLITYCZNE WOJNY DOMOWE? MIT I REWOLUCJA W PRAWICOWEJ POEZJI DWUDZIESTOLECIA MIĘDZYWOJENNEGO
}

PAWEŁ KUCIŃSKI

Wydział Nauk Humanistycznych UKSW

Faculty of Humanities

Cardinal Stefan Wyszyński Uniyersity

in Warsaw

p.kucinski@uksw.edu.pl

ORCID: 0000-0002-1525-1887

\section{I}

Relacje zachodzące między dwoma porządkami: literackim i politycznym, z których pierwszy, wedle klasycznej definicji, tworzy światy prawdopodobne, drugi zaś organizuje świat realny, jednostkowy i społeczny - są jednymi z najbardziej newralgicznych, które podejmuje lub powinien podejmować krytyczny dyskurs kulturowy. Nie tylko dlatego, że polityka - niezależnie od czasu, w którym jest uprawiana i dystansu czasowego, z którego podejmujemy opis - istnieje jako dyskurs „wiecznej teraźniejszości”. Jest swoistym - pragmatycznym - uogólnieniem antropologicznych relacji społecznych. Odzwierciedleniem dynamiki kulturowej. Wówczas - wraz z zapisem literackim rejestrującym zmiany: od jednostkowych po społeczne, zachodzące w grupach i strukturach formalnych (władza) lub nieformalnych (kategorie większości i mniejszości, które można przełożyć na obcość i inność, ideologie stricte polityczne, na opis skomplikowanych stylów życia) - stanowić może dające się zweryfikować i opisać źródło historyczne. Dodatkowo spójna struktura wydarzeń politycznych oraz konieczna pragmatyka działania politycznego, rzadko ujawniającego swoje głębokie, jak w literaturze, znaczenia, mogą być ważnym punktem wyjścia dla odkrycia relacji społecznych mniej skomplikowanych, a jednocześnie - w porządku literackiej ekspresji niemal wstydliwie, bo przecież tylko rzekomo - zasłaniających wieloaspektowość i problematyczność - głębię - ich kulturowego uwikłania. Sprzeciw 
polityczny stanowi wówczas jedynie nikłą część oporu kulturowego, polityczna rozgrywka - nieledwie skromny element walki światopoglądów, które wychodzą poza ciasne ramy ideologii ${ }^{1}$. Może też zapewne zdarzyć się i tak, że polityka pomieszczona w tekstach kultury, w wierszach - wydających się na pierwszy rzut oka jedynie nie dość estetyczną gadaniną, rymowaną publicystyką potrącającą o kicz - stanie się elementarnym zapisem skomplikowanych relacji, które przekraczają nie tylko polityczny i historyczny czas, ale też stanowią antycypację czasu kultury.

$\mathrm{Z}$ tych powodów warto, jak sądzę, analizować pojęcia polityczne i ideologiczne jako budujące ahistoryczne całości kulturowe: wzory zachowań społecznych, które rozpoczynają spór stricte polityczny oraz sposoby dynamicznej społecznej odpowiedzi na zastane (instytucjonalnie i retoryczne) systemy wartości. Polityka nie jest bowiem dyskursem odrębnym od pojęć, którymi żyje antropologia kulturowa. W latach trzydziestych pewien ideologiczny spór, wojna ideowa na wiersze i ułomne metafory, przypomina wojnę kulturową. Ponadto wskazuje na ważne pojęcia, których wieloznaczność, co prawda, każda polityka rujnuje (obcość, wykluczenie, podmiotowość), ale jednocześnie nadaje niektórym z nich inne interpretacje: mit okazuje się pieśnią politycznej przyszłości, rewolucja - ostentacyjną historią i zamkniętą przeszłością; doktryna z kolei - w wierszach politycznych lat trzydziestych uzależniona zostaje od pola znaczeniowego, w którego centrum znajduje się pojęcie (ówcześnie sanacyjnej lub piłsudczykowskiej) władzy.

A jednak to, jak poeci, przede wszystkim ci związani z prawicą (gdyż twórczość poetów lewicowych i lewicujących ma już swoje ważne i doniosłe opracowania $^{2}$ ), traktują te kategorie, wskazuje na rolę nieobcego również w kulturze idealizmu: dziś odpolitycznionej refleksji, która nie powinna ulegać ideowym siłom. Temu wyjaśnieniu natomiast sprzyja nieco paradoksalna antypolityczność, z jaką przyjmujemy literaturę, czy też postulat prak-

1 Zob. np. J. Grad, Wzory kultury a ksztattowanie standardów obywatelskiego myślenia i działania, „Studia Kulturoznawcze” 2017, nr 2, s. 11-23.

2 Na uwagę zasługuje tu wiele pozycji, warto wymienić klasyczne i najwybitniejsze z nich: T. Bujnicki, Bunt żywiołów i logika dziejów, Katowice 1984; idem, Trzy poetyki rewolucyjne, b.m.w. 1968; H. Zaworska, O nowa sztukę, Warszawa 1963; J. Sławiński, Koncepcja języka poetyckiego awangardy krakowskiej, Wrocław 1965; M. Stępień, Wstęp, [w:] Antologia polskiej poezji rewolucyjnej 1918-1939, oprac. M. Stępień, Wrocław 1982. 
tycznej koniecznej niezależności kultury od państwa i polityki. Oczywiście mniemania te, jak wtedy, gdy powstawały, tak i teraz są pięknym ideałem, którego nie da się zrealizować w praktyce społecznej. Przedstawione poniżej wiersze polityczne są dość bolesnym przykładem tego stanu rzeczy, choć sugestia, o której mowa, w normalnych warunkach, w których walka polityczna nie jest prowadzona radykalnie, wymaga od twórców swoistej „politycznej obojętności”.

Dlatego to właśnie ideologiczny radykalizm - jako źródło historyczne i reprezentatywna podstawa analitycznej części niniejszego tekstu - jest rzeczywistym zagrożeniem nie tylko dla literatury, kultury i estetyki, ale również dla społecznych kanonów i wzorów, dzięki którym one funkcjonują. Literatura jako część kultury i jedna z jej instytucji stanowi bowiem ogniwo pośredniczące między demokratycznymi strukturami, które następują po doświadczeniu jednostkowym, tu: lektury dotykającej społecznych (politycznych) problemów a historyczną treścią i kontekstem politycznych wierszy. Czytanie i wybór interpretacji decydują wówczas o miejscu idei w życiu jednostki i społeczeństwa. Bunt przeciwko władzy w latach trzydziestych kreujący atmosferę walki, konfliktu ideowego i wojny domowej, może więc zostać przekształcony i zreinterpretowany. Okazuje się, że relacjonuje napięcie inne - konieczne i obecne w każdym społeczeństwie otwartym: między historią, polityką, etyką a reinterpretującymi je postawami aktorów społecznych, którzy refleksyjnie ważą nie tylko znaczenia (literatury), ale w związku z nimi - sensy współczesnej polityki, odnosząc je do istniejących wzorów kulturowych. Literatura zatem, w tym wypadku odzwierciedlająca strukturę dynamiki relacji społecznych, ze względu na obecność elementu (znaczenia) ukrytego, nie tylko rejestruje polityczną zmianę: jako język pośredniczący ma bowiem wpływ na znaczenia głębokie kultury. W tym troistym układzie, w jakim bierze udział - między antropologią/socjologią z jednej strony a polityką z drugiej - stanowi transmisję, tego co społeczne na to, co polityczne, jednocześnie sugerując coś przeciwnego: odpolitycznienie i uniwersalizację treści politycznych jako stabilnego porządku, który - i na tym polega jej doniosłość - podlega zmianie, a w przypadku totalitaryzmów - co jest niezmiennie groźne może powrócić. Język literatury, korzystając z właściwej dynamiki słowa i znaczenia, uogólnia treści polityczne. Jako takie - mimo radykalizmu zewnętrznego wypowiedzenia - wpisują się (ponieważ literatura „polityczna” otwiera możliwość krytyki metaforycznej 
i symbolicznej) w przedpolityczne, czyli w istocie: negocjacyjne w wariancie optymistycznym, zaś naiwne w wariancie pesymistycznym, praktyki między ideami a tym działaniem. Literatura jako jedna $z$ instytucji kultury może wprowadzać wzory kulturowe w życie (polityczne/społeczne) i vice versa: politykę w szeroko rozumianą kulturę, przy czym transfer ten jest bezstratny. W drugim przypadku jest medium, które w nienegocjacyjnej, historycznej i etycznej funkcji opisuje bądź jest terenem prowadzenia wojen kulturowych. W wypadku wewnętrznego konfliktu w społeczeństwie ujawniają one swój „domowy” charakter. Jakkolwiek zatem należy uznać doniosłość definicji Terry’ego Eagletona, że „określenie »wojny kulturowe« kojarzy się z otwartą wojną populistów z elitarystami, powierników kanonu i wyznawców różnicy"3 (a można do tego dodać: idealizmu z pragmatyzmem, romantyzmu z oświeceniem, marginesu z władzą, mitu z rewolucją), to jedynie polemicznie należy potraktować słowa następne: „Najważniejsze spośród wojen kulturowych dotyczą najzwyczajniej w świecie spraw takich jak czystki etniczne, a nie wartości literackiej dorobku Racine’a czy oper mydlanych"4. Dyskusja z powyższym przekonaniem, prócz prezentacji historycznego konfliktu ideowego, pojęć zyskujących nowe znaczenia i desygnaty, stanowi drugi cel niniejszego szkicu.

\section{II}

Szczególnie w latach trzydziestych postulat antypolityczności wpisuje się w retorykę odrzuconych, ich estetykę i - jeśli takie piszą - w ich wiersze.

Relacja władza (polityka) - opozycja (idea) jest zatem - niezależnie od istniejących wśród niezadowolonych podziałów ideologicznych - ucieczką od historii świata, który za chwilę ulegnie żywiołowi rewolucji: „Walka partyjna jest zła, bo jej rozgrywki toczą się o rzeczy nieistotne, bo oddala, zamiast przybliżać najważniejsze rozstrzygnięcia [...]”, natomiast „walka poglądów jest konieczna tam, gdzie jest ich równocześnie wiele”. „Chodzi o to - pisał jeden z nacjonalistycznych publicystów w latach trzydziestych - by

3 T. Eagleton, Po co nam kultura?, tłum. A. Górny, Warszawa 2012, s. 76.

4 Ibidem.

5 [Gong], Dla dobra ojczyzny, „Kronika Polski i Świata” 1938, nr 16, s. 5. [Pseudonimy poetów, często efemerycznie drukujących na łamach przedwojennych pism, których nie udało się rozwikłać, zapisuję w nawiasach kwadratowych - P.K.]. 
nie prowadzić jej kluczem partyjnym, ale kluczem rozumu serca, energii, pomysłowości, inicjatywy, talentu przewidywania, szerokości horyzontów”6. Taka optyka zmieniała motywację konfliktu między prawicą a lewicą w latach trzydziestych, choć zapewne nie likwidowała wrogości dwóch obozów. Oczywiście, wielość rozwiązań ideologicznych implikuje nie tylko istnienie wroga czy choćby przeciwnika, ale także pozwala uchwycić „moment społeczny” - moment kształtowania się jednolitego dyskursu wymierzonego przeciw polityce i doktrynie jako narzędziom władzy. Oto jeszcze jedna wypowiedź, w tym samym duchu:

Wszelka walka prowadzi z natury rzeczy do pewnego ujednolicenia zagadnień i fałszowania rzeczywistości, nie przestając być jednak konieczną i płodną w następstwa. Rzeczą jest jednak jasną, że artyści patrzący na zagadnienia społeczne przez pryzmat sztuki nie mogą równie serio przejmować się finezją wyróżnień między poszczególnymi ugrupowaniami socjalistycznymi, jak wodzowie czy szeregowcy partii?

Słowa te nie powinny dziwić, a jednak ich autorem jest Jan Nepomucen Miller, który zapoczątkował na łamach „Nowego Pisma” szeroką dyskusję na temat "jednolitego frontu pisarzy" lewicowych, co przy koherentnych intencyjnie głosach nacjonalistów, gdy sprawę uogólnić, wskazuje na podwójne znaczenie rozróżnienia „ideologia - polityka”, niezależnie od pozycji światopoglądowych wypowiadającego.

Antydoktrynalny idealizm młodych radykalnych nacjonalistów można też opisać jako myślenie motywujące, a ideę jako irracjonalną motywację działania, choć racjonalizm polityczny w ogóle wypiera się związku z nieracjonalnym metafizycznym początkiem albo celowo go pomija. Wydaje się, że właśnie świadomość metody i ekstensywność irracjonalizmu, sprawiają, że dla narodowców postawa ta jest bardziej użyteczną metodą polityczną niż racjonalizm, który - zanim zażąda przyjęcia politycznej treści - najpierw oczekuje uznania przez odbiorców swojej „metodologii”. Ale też w grę wchodzi cecha, którą posiada irracjonalizm polityczny. Jest nią transparentność działań podejmowanych w imię woli, uczuciowego napięcia, z którego biorą się działania polityczne, ponieważ:

6 Ibidem.

7 J.N. Miller, Jednolity front ludowy a literatura, „Nowe Pismo” 1932, nr 9, s. 3. 
Irracjonalista [...] w ścisłym znaczeniu tym się znamionuje, że nie wstydzi się idei swoich konstruować świadomie na podstawie własnego duchowego typu; nie wstydzi się też, jeśli się okaże, że idee te nie są logicznym aliażem. Irracjonalista bynajmniej nie gardzi logizowaniem, nie jest mu obojętne, czy zdoła sobie wytworzyć konstrukcje intelektualnie ekonomiczne, przejrzyste; co więcej, on logizuje intensywnie - ale właśnie on, szczery w swoim subiektywizmie uczuciowym, zdolny jest rozbijać wszelakie pseudologizmy, bo jego umysł, sam siebie bezlitośnie obnażając z racjonalizacji błędnych, naciąganych - nie znajduje na dnie tego mułu pustki i otchłani: znajduje swoje istnienie nieprzemożone ${ }^{8}$.

Irracjonalizm, owo „filozoficzne” podglebie idealizmu politycznego, korzysta z racjonalnych narzędzi, by - zdaniem Karola Ludwika Konińskiego wykluczyć to, co w świecie fałszywe, „naciągane” i tylko pozornie mające jakieś znaczenie i wartość. Skoro „osnowa narodu jest metafizyczna”, to narodowiec-irracjonalista musi być w konflikcie z fizykalnym światem, dopóty dopóki idea tego świata nie przemieni:

Rozum irracjonalisty to nie demoniczny rozum bez czynu i woli - to rozum dojrzałości, która, utraciwszy wiele, staje w końcu pogodnie i pokornie przed siłami przeznaczenia: przed determinizmem swej osobowości, której chwytając się oburącz jak mocnej poręczy, dźwiga się ponad rozpacz [...]. Irracjonalizm w ostatecznym, najintymniejszym ujęciu - to moralność bohaterska - metafizycznego ryzyka9.

Zatem „idea narodowa [...] jest to idea bohaterskiego wysiłku wewnętrznego"10.

Zanim jednak kompleks i resentyment staną się osią nacjonalistycznego myślenia młodych narodowców - gdy będą mówić o moralnych stratach, jakie kultura i idealizm ponoszą ze strony racjonalnych sił państwa i wiązanego z władzą, pragmatycznego, cynicznego rozumu - należy zdać sobie

8 K.L. Koniński, Racjonalne - irracjonalne, cz. II, „Myśl Narodowa” 1930, nr 7, s. 101.

9 Ibidem. Zob. też A. Hertz, Socjologia Vilfreda Pareto i teoria elit, [w:] idem, Ludzie i idee, Warszawa 1931, s. 16-17.

${ }^{10}$ H. Eysymontt, Habitus narodowy (dokończenie), „Myśl Narodowa” 1936, nr 4, s. 52 . 
sprawę, że ich racjonalizm ulokowany jest w przyszłości, a używanie go w sprawach doraźnych na nic się nie przyda. „Na to, żeby tylko romantykiem być - pisał zupełnie poważnie Wasilewski - nie trzeba mieć rozumu. Polska jest romantyczna w aspiracjach - jeśli to określenie wystarcza - gdy buduje swoją duszę na przetrwanie wszelkich losów, na najdalszą pełną pracy i ofiar drogę do upragnionego celu, ale jest pozytywistyczną w działaniu, gdy chodzi o wykonywanie zadań wiodących do celu, bo zdołała już zorganizować myśl polityczną"l1. Tylko pierwszą część wypowiedzi młode pokolenie narodowców mogło zaakceptować. Drugą - racjonalizm jako pragmatyzm - radykalni nacjonaliści zdecydowanie odrzucali. Stanisław Piasecki precyzował zatem:

Nowy pogląd na świat [...] różni się [...] wyraźnie od dotychczasowego, podobłocznego światopoglądu idealistycznego. Konkretną rzeczywistością są dla niego zarówno duchowe, jak i materialne potrzeby człowieka. Walcząc o ustrój, w którym by potrzeby duchowe człowieka mogły być zaspokojone, daleki jest od wyniosłej pogardy dla potrzeb materialnych ${ }^{12}$.

Artysta ideowiec, idealista, nowoczesny romantyk, rewolucjonista, jak jego XIX-wieczni poprzednicy, zgadza się na niepełność swoich sądów o polityce, której przeciwstawia pewność i wiarę w słuszność idei, której polityka jest tylko częścią; odróżnia doktrynę od wizji, więcej nawet: ignoruje pragmatyzm i analityczność doktryny na rzecz koniecznego dla ideologicznego wizjonerstwa - irracjonalizmu. Jak romantyk, gotów jest poznanie rozumowe zawiesić na rzecz intuicyjnego:

Jeśli pojawia się możliwość dla artysty, by wypowiedział swoje aktualne zdanie w sprawach politycznych, rzuca on, jak dziecko wprowadzone do nieznanego pokoju, szereg pytań, dla zawodowego polityka mniej lub bardziej naiwnych, niekiedy niezrozumiałych, nieraz śmiesznych ${ }^{13}$.

Zdecydowane wykluczenie obecności doktrynerstwa w literaturze ma doprowadzić, po pierwsze, do powstania pojęć odrealnionych, po drugie: do ich

11 Z. Wasilewski, Orientacja wewnętrzna, Moskwa 1916, s. 12.

12 S. Piasecki, Z pieca na łeb, [w:] idem, Prawo do twórczości, Warszawa 1936, s. 44.

13 M. Wiśniewicz, Artysta o polityce, [w:] Tworzymy nowy dział [artykuł redakcyjny], „Ruch Kulturalny” 1937, nr 2, s. 18. 
demistyfikacji, jeśli należą do słownika politycznych opozycjonistów. Sami jako podmioty własnych współczesnych ideowych narracji, a dziś również świadomi użytkownicy mitów politycznych, których krytyka jest niezbędna, możemy, jak przed wiekiem, tworzyć je i poddawać refleksji. Różnica polega jednak na tym, że, jak się wydaje, lata trzydzieste tworzyły imponderabilia i hipostazy niejako niepodatne na możliwość racjonalnej oceny. Nie była ona zakładana. Naród, Państwo, Lud, Patriotyzm - a przynajmniej przekonanie o apriorycznej niemożliwości „wiersza politycznego” sensu stricto jako formuły, której jedynym przeznaczeniem jest zadośćuczynienie celom błahym, partykularnym i doraźnym - wspierało się wówczas na węższej, funkcjonalnej interpretacji idealizmu, dla którego antywartością nie jest już racjonalizm, a materializm ${ }^{14}$. Wówczas „idealizm” staje się swego rodzaju intencją narodowej twórczości, a zarazem dookreśla swoje przeciwieństwo - wroga ideologicznego, którym pozostaje dla prawicy bolszewizm i jego „zwyrodniała", jak pisano w prasie prawicowej, filozofia - marksizm. Stanisławowi

14 Tak ujmuje idealizm, związany z przedwojennym nacjonalizmem, przywódca słynnego „marszu na Myślenice”, Adam Doboszyński. Idealizm to w jego ujęciu zbieżnym zresztą z przedwojennymi eksplikacjami nacjonalistów - „pogląd na świat przyznający pobudkom idealnym, religijnym, etycznym, narodowym, wypływającym z uczuć przywiązania do rodziny, ziemi, ojczyzny itp. czy też związanym z realizacją pewnych oderwanych idei, większy wpływ na dzieje ludzkości i losy poszczególnych jednostek niż względom gospodarczym. Idealizm stanowi przeciwieństwo materializmu" (A. Doboszyński, Mała encyklopedia pojęć społecznych, Londyn, b.d.w., s. 24). Antyteza idealizm-materializm miała charakter bardziej ideologiczny od (jak wiemy) nie zawsze neutralnego zestawienia idealizmu z racjonalizmem: idealizm wedle tej kategoryzacji to „po prostu” „wiara w możliwość zrealizowania pewnych ideałów oraz dążenie do ich zastosowania w życiu. Przeciwieństwem idealizmu jest realizm, który zadawala się rzeczywistością i tylko z nią się liczy" (A. Peretiatkowicz, Współczesna encyklopedia polityczna, cz. II, Poznań-Warszawa 1926, s. 252). Na ideologiczny charakter rozróżnienia idealizmu i materializmu naprowadza słowo wstępne Doboszyńskiego z cytowanej Encyklopedii, która ma być „wolna od balastu osiemnasto- i dziewiętnastowiecznej myśli, który ciąży na wszystkich dotychczasowych encyklopediach polskich. Dwa wieki »oświecenia« chciały wytępić "przesądy« religijne i inne - i w rezultacie nagromadziły taką stertę przesądów, uprzedzeń i pseudo-naukowego doktrynerstwa, że w gąszczu tym zagubiły się zdrowa myśl i prosty rozum" (A. Doboszyński, op. cit., s. 3). 
Piaseckiemu przydawało się powyższe instrumentarium teoretyczne, gdy pisał, że: „marksizm jest doktryną. Nacjonalizm nie jest doktryną. [...] Bez tego ani kroku naprzód. Uprzytomnienie sobie tej zasadniczej prawdy dlatego jeszcze jest niezbędne, że słowa »marksizm « $\mathrm{i}$ »nacjonalizm «, $\mathrm{z}$ ową jednobrzmiącą końcówką »-izm «, stwarzają zewnętrzny pozór jakiejś jednopłaszczyznowości pojęciowej” ${ }^{\prime 1}$. Autor Prawa do twórczości z rozbrajająca szczerością deklarował więc, że:

chętnie już teraz wyrzeklibyśmy się słow a „nacjonalizm”, aby położyć kres fałszywym asocjacjom izmowym, gdyby przekora i duma nie kazała nam go podtrzymywać: właśnie dlatego, że jest takie zohydzane, [...] że zrobiono zeń straszaka [...], że na nie napadaja ${ }^{16}$.

„Skończmy z »nacjonalizmem «, tak samo jak skończyliśmy z liberalizmem, demokratyzmem i tylu innymi idiotyzmami XIX stulecia"17 - apelował Tadeusz Gluziński. Wiele wskazuje na to, że „izmy” i ukryta za nimi polityczność mogą być traktowane jako słowne, pojęciowe stereotypy. Właśnie dlatego chodzić może nacjonalistom o negatywną wartość skojarzeń, które polityczne ,izmy” wywołują, a zatem - niską wartość propagandową „nazw” i politycznego szufladkowania. Zwracał na to uwagę Aleksander Hertz:

Zwolennik Stronnictwa Narodowego niechętnie sam nazwie się „,endekiem” nazwy tej używają przeważnie przeciwnicy tego kierunku. Najważniejsze jest jednak to, że w [...] tych wypadkach komponentami treści, jakie istnieją w umysłach ludzi, którzy się tymi nazwami posługują, jest ograniczona ilość elementów silnie emocjonalnie zabarwionych ${ }^{18}$.

Chyba także dlatego, że „izmy” źle się kojarzą, Gluziński pisze prowokacyjnie, że „młody polski ruch narodowy nie jest »nacjonalizmem " i proponuje, by ta „niefortunna nazwa [...] znalazła się w muzeum mało szacownych pamiątek tych lat, w których Polacy żyli w oparach cudzego oddechu"19.

15 S. Piasecki, Słowo i treść, [w:] idem, op. cit., s. 103.

16 Ibidem.

17 T. Gluziński, Odrodzenie idealizmu politycznego, Warszawa 1935, s. 31.

18 A. Hertz, Rzeczywistość społeczna i jej obraz, [w:] idem, Socjologia współczesna, Warszawa 1938, s. 99.

19 Zob. T. Gluziński, op. cit, s.31. 
Takie dystansowanie się nacjonalistów od nacjonalizmu stawiałoby polski nacjonalizm w sytuacji paradoksalnej, gdyby nie jedna ważna przesłanka. Piasecki woli ideologię, której treścią jest walka , „warunkowo” godzi się na słowo „nacjonalizm” z całą jego „niefortunną politycznością”, ponieważ: „Uciekanie od słowa, choćby niefortunnego, jest tym samym, czym opuszczanie sztandaru. Nie opuszcza się sztandaru w walce. Można go zamienić

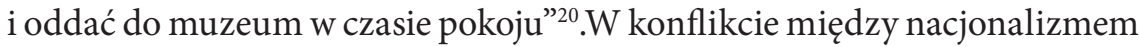
a marksizmem, walce jednoznacznie ideologicznej, a nie politycznej, jako argument rzekomo stojący za idealizmem znów pojawiał się romantyzm. Wystarczyło jedynie skojarzyć historyczny oświeceniowy sceptycyzm i racjonalizm z „komunistycznym” ateizmem i materializmem, rewolucję francuską z bolszewicką, tamten terror $\mathrm{z}$ terrorem „czerwonym” ${ }^{21}, \mathrm{z}$ „,czerwonym caratem”, a skojarzeniom tym przeciwstawić „romantyczny chrystusowy nacjonalizm", jedyną pozytywną odpowiedź w rzekomo zdemoralizowanym świecie wschodniego i zachodniego totalizmu. Przekonanie młodych, że:

Wtłoczeni między krwawiącą swastykę

i kraj zachlapany krwią,

między zbrodnię i pogańskie mity,

spełnimy odwieczne powołanie $\mathrm{e}^{22}$

było powszechne, toteż najważniejsza z tych, przeprowadzanych doraźnie, acz funkcjonalnych ideowych paralel (o nacjonalistycznym idealizmie i materialistycznym ateizmie, o barbarzyńskiej wschodniości ${ }^{23}$ i okcydentalizmie jedynej prawdziwej kultury w świecie bez zasad) głosiła, że: „romantyzm

${ }^{20}$ S. Piasecki, op. cit. s. 105. Tę ucieczkę od „izmów” potwierdzał po latach W. Wasiutyński: „Obóz narodowy sam nie określał się jako »nacjonalistyczny«, wychodząc z założenia, że to określenie zawiera w sobie element doktrynalny i sprowadza obowiązek narodowy do części jakby tylko społeczeństwa” (W. Wasiutyński, Nacjonalilzm, [w:] idem, Słownik polityczny, Nowy Jork 1980, s. 96).

${ }^{21}$ Zob. M. Zdziechowski, Czerwony terror, [w:] idem, W obliczu końca, Warszawa 1999.

22 W. Pomykaj, Przysięga. Z Poematu o Wielkiej Polsce, „Orlęta” 1938, nr 6, s. 79.

${ }^{23}$ O azjatyckości, tudzież innych stereotypowych prezentacjach bolszewików w poezji i satyrze lat 1918-1932 zob. E. Pogonowska, Dzikie biesy. Wizja Rosji Sowieckiej w antybolszewickiej poezji polskiej lat 1918-1932, Lublin 2002. 
polski jako światopogląd, kierunek społeczny i polityczny był bodaj jedynym w Europie nowoczesnej silnym buntem przeciwko materializmowi" ${ }^{24}$. W ten sposób młodzi manifestowali odrębność ideologiczną. Historyczny racjonalizm zostaje zastąpiony uosobieniem wszelkiego zła, jak najbardziej współczesnym i o wiele groźniejszym od wiary w potęgę rozumu sprzed dwustu lat, a nawet jednoznacznie wrogim, bowiem w programach i ideologiach

zawsze były $\mathrm{i}$ będą odcienie oraz jedna głęboka i istotna różnica [...]: między materialistycznym a idealistycznym oglądem na świat, czyli przetłumaczywszy to na współczesny język polityczny: kierunkiem narodowym a kierunkiem komunistycznym ${ }^{25}$.

W tym duchu przemawiają również poeci narodowi. Wiersze ich często apelują do robotnika, ukazując jego uwikłanie w światopogląd materialistyczny, które nacjonalista obnaża. Prezentuje fałsz i proponuje inną drogę, pełną, totalną, gdzie potrzeby i emocje proletariuszy są zaspokojone. Oczywiście w grę wchodzi polityczna agitacja, jednak kategoryczny „fałsz”, który poeci radykalni wydobywają na podstawie własnej eksplikacji marksizmu, ma sankcję tyleż „partyjną" i ideologiczną, co „moralną”. Wiersz Stanisława Gębali o charakterystycznym tytule Odpowiedź czerwonemu koledze prezentuje nacjonalistyczne „ja”, które „wie więcej”, bo jest reprezentantem czystej idei polskiej - miłości do ziemi, jaką może mieć tylko "prawdziwy Polak":

Więcej krzyczy mój pług,

Krzyczy głód, przednówek...

Chcesz, bym pług rzucił

I szukać szedł pełnego koryta ${ }^{26}$.

Chłopskie „ja” uświadamia „czerwonego kolegę”. Sobowtóryzacja, wskazująca na podwójną, nienaturalną dla „polskiego” robotnika moralność, przy jednoczesnym, niezbędnym dla polskiego nacjonalizmu uznaniu roli

${ }^{24}$ W. Wasiutyński, Czucie i szkiełko, [w:] idem, Z duchem czasu, Warszawa 1936, s. 13.

25 S. Piasecki, Co nas dzieli?, „Prosto z Mostu” 1936, nr 37, s. 1.

26 S. Gębala, Odpowiedź czerwonemu koledze, „Prosto z Mostu” 1936, nr 11, s. 2. 
Opatrzności, pozwala mówić o intencji podmiotu: „nawróceniu na idealizm" - misji, jakiej podjął się poeta-narodowiec:

Nie wiesz tylko, że w świecie jest drugi świat,

Ten za korytem,

Że jesteś ty i w tobie drugi Ty,

Co, gdy ty idziesz ziemią, On idzie po niebie,

Co, gdy ty patrzysz w słońce, On patrzy na ciebie,

A gdy grzebiesz w korycie - w słońce patrzy za ciebie,

Ten drugi $\mathrm{Ty}^{27}$.

Agitacja polityczna, walka o rząd „robotniczych” dusz, czasem więc przybiera formy (może zanadto) intelektualne. Bardziej właściwe poetom narodowym jest mówienie wprost. W wierszu Chłopie i robotniku zjawia się użyty do celów agitacji politycznej stereotyp „żydokomuny”:

Czy myślisz, że Żyd, który nocą

rozwiesza portrety Lenina -

i drugi - poeta z kawiarni -

i trzeci - komisarz Kompartii -

po to się tak poświęcają,

byś z dziećmi z głodu nie ginął,

byś nie gnił w chorobie i nędzy,

żebyś o chleb się nie martwił?

[...]

A co będzie, jak się omylisz -

i po wyrżnięciu burżuazji

piętnastu milionom kułaków

przystawią lufy do łbów -

jak naród ze Śląska i Łodzi

pognają boso do Azji,

jak będzie Sowiet żydowski,

ich rząd? Co wtedy? Mów!28.

Głos poetów narodowców podniesiony za robotnikami, w ich imieniu, pokazywał, że w przeciwieństwie do marksizmu idealizm miał cel, którym

27 Ibidem.

28 T. Dworak, Chłopie i robotniku!, „Myśl Narodowa” 1937, nr 10, s. 153. 
był naród i tajemnica narodowej tożsamości. Ukazywano hierarchię,: „Najpierw jest się Polakiem - potem robotnikiem, chłopem czy rzemieślnikiem. Walka klas dzieląca Naród na wrogie odłamy jest wyrazem fałszywej hierarchii celów, jest wyrazem - zapanowania egoizmu nad altruistyczną miłością do Narodu"29.

Właściwie „bycie Polakiem” na pierwszym miejscu rozstrzygało problem języka polityki, także w poezji. Był sztuczny, bo nie miał oparcia w idei wyższej niż doraźna intencja - idei, która zamiast dzielić naród, powinna łączyć. Marksizm usiłuje zniszczyć ideę narodową:

Pamiętaj! Łącz się i walcz! -

gdy źle ci, gdy puchniesz z głodu bo rodzisz się - człowiek do życia, a nie ścierwo do tłuczenia świń ale nie kładź łba na pień rzezakom od uboju narodów, z powaleniem głowy na ziemię, $\mathrm{z}$ babraniem się we krwi! ${ }^{30}$.

W polskim, również poetyckim nacjonalizmie nie da się pominąć tych solidarnościowych pomysłów, które na poziomie społecznym zapewniają poczucie tożsamości i jedności. Propaganda skupienia narodu w jedno, w czym przeszkadza „stanowa” przeszłość Rzeczpospolitej", ale też rozbijający naród „na wrogie klasy” marksizm, jest próbą ustanowienia modelu perswazji totalnej - wobec takich argumentów właściwie nie można wysunąć jakichś kontridei, nie można dyskutować z idealną, ale i historycznie bardziej pierwotną niż klasa i stan ideą narodu, która jako jedyna - w odróżnieniu od podziału klasowego - nie działa na szkodę jedności i wspólnoty. Poniższy wiersz mógłby być niemal socrealistyczny i pochodzić z innej epoki, gdyby nie jego „niekolektywna” wymowa, pełna nie do końca zawoalowanej groźby:

29 W. Zaorski, Walka światopoglądów, „Ruch Młodych” 1936, nr 10-11, s. 35.

${ }_{30}$ T. Dworak, op. cit.

31 Zob. W.J. Grabski, Poczucie historyczne Polaków, „Ruch Kulturalny” 1937, nr 2. 
Nieznana rzesza cichych pracowników,

Bohaterów nieznanych - dni naszych tak szarych

Bez gwaru i hałasu, rozgłosu i krzyku

W świat nowy przekuwa - zgnuśniały świat stary.

W łoskocie spadających na kowadła młotów

W cichej ofiarnej i nieznanej pracy

Zespolili się wszyscy prawdziwi Polacy

Nad całą Polską głosem potężnego grzmotu

Wyobręczył się wielki, potężny hymn pracy ${ }^{32}$.

Nie można jednak zapominać o tym, że wspólna tożsamość zależy od „bycia Polakiem” w znaczeniu, jakie nadał temu pojęciu (i tej aktywności, która po latach przejdzie w agresywność powodowaną nienawiścią) Roman Dmowski, jeszcze przed wojną uznawszy łączność dzisiejszych pokoleń z przeszłymi i tymi, które nadejdą po nich ${ }^{33}$. W tym sensie lewica, która wprost artykułowała swój sprzeciw wobec tradycji ${ }^{34}$, widząc jedynie bezklasową przyszłość, nie była idealistyczna, a wyłącznie - w negatywnym znaczeniu tego terminu - polityczna, doraźna, funkcjonalna. Z drugiej zaś strony, mimo frontalnych ataków na lewicę, nacjonaliści zupełnie gdzie indziej widzieli prawdziwe zniewolenie współczesnego człowieka. Bezkompromisowe postawienie kwestii „wolności” ma kilka ważnych konsekwencji. Pozwala

32 [De-ka], Hymn Pracy, „Orlęta” 1930, nr 8, s. 3.

33 Zob. R. Dmowski, Myśli nowoczesnego Polaka, wyd. XII popr. i uzup., wstęp N. Tomczyk, Poznań 2002, s. 19. Chodzi tu o najbardziej znany chyba fragment książki przywódcy endecji, zaczynający się od słów: „Jestem Polakiem, to znaczy, że należę do narodu polskiego...”. Hasło: „Jestem Polakiem” stało się niemal znakiem rozpoznawczym orędowników idei prawicowej.

34 Zob. J.N. Miller, Karol Radek o położeniu literatury światowej, „Lewy tor” 1935, nr 2: „Wstępujemy w historię jako bunt przeciw tradycji. Przykuci łańcuchem do przeszłości napinamy swe mięśnie i wytężamy swe siły, aby więzy te zerwać i ruszyć naprzód przed siebie. Staramy się więc zerwać z tą przeszłością jak najgruntowniej. Wytwarza się zasadniczy antytradycjonalizm. Jesteśmy uczuciowo nastawieni na przeciwstawienie się przeszłości. I słusznie. Bez wątpienia, że metoda taka widzenia walki jest generalizowaniem i [...] przesadą. [...] Z punktu widzenia walki jest ona koniecznością [...]. Idziemy przeciw przeszłości - oto hasło. Nie ma tu miejsca na zastanawianie się nad tym, że w owej przeszłości są również czynniki dodatnie" (ten sam cytat podaje A. Górski, zob. idem, Niepokój naszego czasu, Warszawa 1938). 
krytykować działania władzy na poziomie idealnym i z tej perspektywy eksplorować ów „gnuśny” świat polityki racjonalnej i opresyjnej.

Antywzorzec obywatela, na który zwracają uwagę narodowcy, w publicystyce państwowej funkcjonował jako wymyślony na potrzeby propagandy, wsparty siłą państwa i mitem posłuszeństwa, które już nie tyle legitymizowały instytucję, co najpierw wytwarzały ślepą wiarę niewolonych. I niewiele mogły zdziałać tu argumentacje „państwowców”, że „»szary człowiek« nie jest pojęciem współczesnym i żadną miarą nie da się pogodzić z wielkimi prądami społecznymi, nurtującymi współczesną ludzkość" ${ }^{35}$, że:

Szary człowiek to spadek po tych czasach, kiedy między grupą rządzącą a grupą rządzoną, a masą rządzoną istniała przepaść nie do przeżycia. [...] Dziś jednak świat inaczej już wygląda. Bo jeśli nawet weźmiemy pod uwagę państwa, w których panuje régime dyktatorski, to zobaczymy, że człowiek $\mathrm{z}$ tłumu ani rusz nie zasługuje na nazwę szarego człowieka. Jakkolwiek bowiem jego wolność osobista jest często mocno ograniczona ze względu na interes ogólny i podporządkowania panującej w państwie ideologii, to jednak udział jego w życiu społecznym [...] i stopień ponoszonej odpowiedzialności za wykonywaną pracę - są tak wielkie, że ów wewnętrznie skrępowany człowiek staje się czynnikiem pełnowartościowym, bynajmniej nie bierną istotą, mechanicznie posuwaną na szachownicy ${ }^{36}$.

Coś jednak było na rzeczy, a narodowców zapewne takie argumenty nie przekonywały, gdy to słowa np. Wojciecha Bąka:

Przy maszynach oszalałych wirem

Chodzisz - robot - ogłuchły i tępy - ${ }^{37}$

wyrażały „najistotniejsze cechy polskiego, młodego, dynamicznego nacjonalizmu, pragnącego wznieść Polskę wyżej i przebudować jej psychikę"”38, a właśnie uwikłany „w maszynę” Państwa człowiek był symbolem zniewolenia $\mathrm{w}$ poezji:

35 J.E. Skiwski, Mania szarzyzny, „Pion” 1936, nr 28, s. 1.

36 Ibidem.

37 W. Bąk, Bałwochwalcom XX wieku, cyt. za: S. Piasecki, Coraz szerzej..., „Prosto z Mostu" 1936, nr 50, s. 1.

38 S. Piasecki, Coraz szerzej..., „Prosto z Mostu” 1936, nr 50, s. 1. 
Nie! Nie! Niczym jest człowiek! Kółeczkiem w maszynie,

Które majster, kiedy chce, i jak chce, nakręci.

Duch! Czyż Duch-by możliwy był w podłej łupinie,

Pełnej niesfornych myśli i skłóconych chęci?

Kapitał! Oto jedyna komun totalnych dusza!

Pieniądzem historia się wszczyna,

Pieniądzem epoka się wzrusza! ${ }^{39}$.

„Człowiek jest niepotrzebny, zbyteczna robota / Zastąpiona została rozumem robota” ${ }^{40}$ - pisali poeci, dla których „państwo kapitalizmu prywatnego czy publicznego” stało się „państwem niewolnictwa”41. „Kapitalizm - dochodził do podobnego wniosku Pietrzak - odcina człowieka od prawd bezwzględnych. Zatrzymuje go i więzi w ciasnym kręgu doczesnym. Kultura, w której się urodziliśmy i którą odrzucamy, przyjęła za cel [...] złote wory wiadomości. To była kultura skąpstwa, kultura ślepych"42.

W latach trzydziestych te ideały zmieniły się. Gdy już wiadomo było, że państwo nie spełniło pokładanych w tej idei przez lata niewoli nadziei, a krytyczna „radość z odzyskanego śmietnika” przerodziła się w siłę wymagającą od obywatela automatyzmu gestów, spełniania obowiązków za „miskę soczewicy”", nacjonalizm walczył o „nowy typ człowieka, który nie byłby niewolnikiem maszyny”44. Nacjonaliści „wstawiają się” za „szarym”

39 S. Sapiński, Rapsod krwawiacy o całym człowieku, [w:] idem, Żagiew palaca, Kraków 1939, s. 26.

40 A. Jałta-Połczyński, Mechaniczny pilot, „Prosto z Mostu” 1936, nr 1, s. 1.

${ }^{41}$ W. Wasiutyński, Praca?, [w:] idem, $Z$ duchem..., s. 135.

42 W. Pietrzak, O nowoczesna kulture narodowa, „Młoda Polska” 1937, nr 2, s. 17.

${ }_{43}$ Zauważali to nie tylko nacjonaliści. Mieczysław Szerer pisał: „Propagowanie państwa jest w istocie rzeczy ubliżaniem społeczeństwu, wśród którego się je uprawia albo ubliżaniem państwowości, która je uprawia. Potrzeba takiej propagandy jest bowiem albo dowodem, że umysłowość lub moralność społeczeństwa pozostają na kompromitująco niskim poziomie - na tym, na którym nie ogarnia się elementarnych pojęć cywilizacji; albo dowodem, że państwowość nie spełnia swego zadania" (zob. M. Szerer, Śmiertelni bogowie. Rzecz o demokracji i dyktaturze, Warszawa 1939, s. 26). $\mathrm{Z}$ drugiej strony dowodził także, że każda „dyktatura nadużywa idei państwa, zupełnie tak samo jak nacjonaliści nadużywają idei narodowej. Jedni i drudzy czynią z rzeczy pięknej i godnej największego szacunku rozdętą karykaturę" (ibidem, s. 23).

${ }^{44}$ S. Piasecki, op. cit., s. 1. 
człowiekiem”, ale też podsycają do buntu i prowokują: „Czcijcie, obywatele, swoje niewolnictwo, bądźcie dumni, że nie tylko jecie i śpicie, ale i pracujecie! [...] Szary człowieku, czy jesteś głupim człowiekiem?"45 - pytają i właśnie tę „ideologiczną” „szarość” chcą przełamać:

Mówicie, że szaro wstaje co dnia życie, że szaro patrzą nam oczy, że w fabrykach gniecie nas jazgot, miażdżony błyskami trybów, Wózki w kopalniach węgla czarną powszedniość toczą, a na wsi pług pola rozkłada w jednostajne, żałobne skiby.

Mówicie, że wracamy do domów zgubieni w ulicznych gwarach, by kolacje, mdlejące parą, zawlokły wzrok nasz do łóżka, gdzie sny też szare ${ }^{46}$.

Chcą zachwycić inną „miarą zwyczajności”, z której bierze się prawdziwa twórczość:

Nad widnokręgiem z radości mruży się biała pogoda, jeśli przechylisz zachwyt, usłyszysz w syrenach świerszcze, a zamiast dźwięków zobaczysz barwy w codziennych słowach ${ }^{47}$.

Pietrkiewicz nie godził się na hipostazę „nowoczesnej” rzeczywistości, apoteozę życia dla niego samego:

Nie mówcie, że ludzie są szarzy, gdy wzrok od życia jest szerszy, świat tylko nie ma swej twarzy! ${ }^{48}$.

I - w końcu - upolitycznionej szarzyźnie przeciwstawiał feerię idei. Bowiem tylko

Naród jest kolorowy! ${ }^{49}$.

45 W. Wasiutyński, Praca?, [w:] idem, $Z$ duchem..., s. 135.

46 J. Pietrkiewicz, Kolorowi ludzie, „Prosto z Mostu” 1936, nr 15-16, s. 3.

47 Ibidem.

48 Ibidem.

49 Ibidem. 
Poezja, która (jedynie rzekomo) nie tworzy politycznych przepisów, ma wyłącznie wspierać tezę, że tylko naród zapewnia bezpieczeństwo i - innymi niż marksizm sposobami - doprowadza do ideału. Jako prawicowa odpowiedź na lewicową bezklasowość w wierszach nacjonalistycznych:

Inżynier,

Robotnik,

Chłop,

Student

- bezklasowy, bo zwarty szereg -

$[\ldots]$

stoją jak zwycięskie, kohorty

Radosne i karne, zwycięsko ofiarne -

Słońca są pełne aorty ${ }^{50}$.

Uniwersalizm dążeń i dostępna dla wszystkich Polaków idea narodowa wiodą życie „prostego człowieka” ku celom istotnym, „równym prawom i obowiązkom", zapewniają także emocjonalne uniesienia; obiecują mu przedsięwzięcia nie tylko egoistyczne i puste, ale podejmowane w imieniu zbiorowości, w których będzie uczestniczył jako pełnoprawny członek narodu:

Jesteśmy idealistami - deklarują nacjonaliści - i stoimy na stanowisku, że nie materia rządzi duchem, a odwrotnie - człowiek nie rządzi się i nie powinien - egoizmem; ofiarność i zdolność do służby dla Narodu - oto cechy prawdziwego człowieka. To tłumaczy, że jesteśmy nie tylko przeciwnikami, lecz wrogami marksizmu; materializm grzeszy bowiem wobec duszy polskiej, a zasadą walki klas - przeciw jedności tych dusz ${ }^{51}$.

Zdarzało się jednak, że nacjonaliści oddawali sprawiedliwość swym ideowym przeciwnikom:

Socjalizm polski tak długo zachowywał charakter ruchu rewolucyjnego, jak długo ożywiały go pobudki idealistyczne. Gdy zaczął czerpać podniety

50 W. Gołański, Przewrót, „Orlęta” 1937, nr 1, s. 8.

${ }^{51}$ W. Zaorski, Walka światopoglądów, „Ruch Młodych” 1936, nr 10-11, s. 35. 
z podłoża ekonomicznego, jego aktywność bojowa osłabła. Jest to zjawisko zupełnie naturalne i uzasadnione. Człowiek współczesny chce odnaleźć w ruchu ideowym zasadniczy cel i sens swojego istnienia. To co stanowi jedynie warunek utrzymania życia, nie może być ukoronowaniem wszystkich wysiłków i natężeń. Ginąć za misę soczewicy potrafi tylko człowiek-zwierzę, istota pozbawiona aspiracji wyższych ${ }^{52}$.

Postawa ta mogła stwarzać pozory politycznej dojrzałości, wszak ortodoksyjna prawica dawała tym gestem do zrozumienia, że potrafi prowadzić „dialog” z „duchami przeszłości”, które uosabiał socjalizm przedrewolucyjny, marksowsko-engelskowski.

Koncepcja walki ideologicznej, którą prowadzić ma ideowa literatura, a w niej, jak w zwierciadle, odbijać ma się naród prowadzi - w myśl idealistycznych założeń - do poezji, która pod hasłami solidarności przedzierzgnie niedawnych wrogów w adherentów, będzie walką o wartości ${ }^{53}$.

Narodowcy szybko dostrzegli, że najpewniejszy skutek przynosiło uderzenie w marksizm oskarżeniami o elementarną niezrozumiałość tej doktryny, o „płytki” oddech ideologii. Właśnie w poezji, która miała kształtować charaktery, nie było miejsca na idealistyczny socjalizm - materializm odczytywany był jako fałsz i propagandowa sztuczka. Nacjonalistycznej dekonspiracji podlegał przede wszystkim język marksistów, a z nim i „ich” rewolucyjna, polityczna poezja.

52 A. Łaszowski, Nacjonalistyczny człowiek przełomu, „Falanga” 1938, cyt. za: A. Łaszowski, Nacjonalistyczny Człowiek Przełomu, https://www.nacjonalista. pl/2018/08/20/alfred-laszowski-nacjonalistyczny-czlowiek-przelomu [dostęp 11.04.2021].

53 „Walka klas oczywiście istnieje, nie ulega ona wątpliwości. Ale komuniści chcieliby wszystkie walki społeczne na świecie zredukować do jednej: między komunizmem a faszyzmem, inne walki zaś gotowi uznać za pozorne, fałszywe, komedianckie, dywersanckie itp. Naprawdę zaś rzecz ma się tak, że panuje [...] wojna wszystkich ze wszystkimi, klasy, warstwy i grupy już to walczą na dwa fronty lub kilka frontów, już też wchodzą z sobą we wzajemnie w sojusze, posługują się sobą wzajemnie, »wygrywają się" przeciw sobie wzajemnie, jak im interes każe. Interes! A więc interes materialny? $\mathrm{Nie}$, nie tylko materialny. Jest też interes narodowy, religijny, obyczajowy. Że wspomnę np. antysemityzm” (K. Irzykowski, O perfidii i szantażu, „Prosto z Mostu” 1935, nr 30, s. 1). 
Stanisława Sznaper w wierszu Do poetów społeczników bez ogródek i wprost demaskowała poezję rewolucyjną:

Ja pierwsza serce sobie dam rozerwać.

Serce ważne i tchórzliwe, jak każdego $\mathrm{z}$ was, Egoiści! $!^{54}$.

Eksklamacja, bardziej publicystyczna niż poetycka, prosta i mało wyrafinowana, miała jednak swoją ważną funkcję. To jeden $\mathrm{z}$ wielu w narodowej poezji „gestów szczerości” - odmiana nacjonalistycznej czy ogólnie ideologicznej, figury poetyckiej, której funkcją jest przekonanie publiczności albo nawet przejęcie tej jej części, którą można nazwać „lewicową”. To walka o ideowego czytelnika wirtualnego, $\mathrm{w}$ tym sensie, $\mathrm{w}$ jakim potencjalnym jest również ideologiczny elektorat, który Dobrzyński - bardziej po „endecku" ${ }^{\prime 5}$ niż marksistowsku - zgodnie z priorytetami nacjonalizmu młodych utożsamia z ludem:

Nie damy ludu wodzić po złudnych manowcach

wśród waszych rui i poróbstwa wzruszeń,

lecz mu odkryjem naszą polską duszę

i damy do spożycia jak bochen razowca ${ }^{56}$.

Wiersze jednak dość znacznie różnią się na poziomie poetyki, a ściślej: odmienna jest konstrukcja podmiotów lirycznych, przez co ideologizacja przebiega w każdym z nich nieco inaczej. W wierszu Dobrzyńskiego rządzi

${ }^{54}$ S. Sznaper, Do poetów społeczników, „Prosto z Mostu” 1936, nr 22, s. 2.

55 Ludowy charakter nacjonalizmu endeckiego to przede wszystkim naturalna, niewymuszona, eugeniczna „polskość” mas nieposiadających: „Człowiek oświecony nieraz tak się wynaturzy, że uczy się z nakazu szkolnego tradycji narodowych i te go się nie imają, a lud je pamięta bez nauki, przechował je we krwi żywej. Romantyzm zeszłego wieku, sięgając po przywileje poetyckie ludu, zrobił na tym tle rewolucję umysłową i wiele »nieczułych lodów « przysnęło. Ale dopiero w sto lat później z dojrzałości własnej doszliśmy do naturalnego z tradycją obcowania. Już się nie widzi przeszłości a la Burger, Walter Scott, Rychter, Shiller, Novalis, czy kto tam, ale po swojemu - chwyta się ją koncepcjami polskiej myśli nowożytnej i stylizuje się ją w sztuce formami swojskimi”" (Z. Wasilewski, Listy dziennikarza w sprawie kultury narodowej, Lwów 1908, s. 66).

${ }^{56}$ K. Dobrzyński, Bunt, [w:] idem, Czarna poezja, Poznań 1936, s.118. 
wyraźne ideologiczne „my”, podmiot zbiorowy, „polski”, o weryfikowalnym światopoglądzie. „Odkrycie duszy” polskiej, spożycie jej „jak razowca” przenosi gest szczerości nacjonalisty w czwarty wymiar - uruchamia metafizykę, a jednocześnie otwiera słowo narodowe na symbolikę „razowego chleba”, zwykłości, ale też „religijnej tradycyjności”. Przy tym „rozerwane serce” Sznaper jest bardzo przyziemne, choć niemniej „tragiczne” w wymowie. Jeśli jednak wziąć pod uwagę, że w wierszu tym pojawia się klasyczne „ja” liryczne, to ta „szczerość” poetki, która „rozrywa serce”, okaże się bardziej wymowna, a w sensie propagandowym może lepiej spełniać funkcję perswazyjną, nie tylko dlatego, że znaczenia wiersza Do poetów społeczników są bardziej literalne. Dusza Dobrzyńskiego swoim patetycznym stylem, który implikuje poeta, religijnością, którą ten motyw przywołuje jako kontekst dla rozpowszechnionych w poezji figur i zapewne zachowań proponowanych jako doświadczenia indywidualne własnym czytelnikom, nie równa się prostemu gestowi, który dla każdego osobny wypływa $\mathrm{z}$ bezpośredniego doświadczenia poety i rezonuje w bliskim odczuciu zagrożenia - w odbiorcy, pogrążonemu w lekturze wiersza Sznaper.

Dobrzyński przeciwstawia swoje „my” - „im”, wrogom, ale oprócz wskazania na dwie skonfliktowane grupy, mówi niewiele o polityce, więcej zaś o ideologii. U Sznaper zaś obie grupy zostają podzielone również na zasadzie ilościowej, a polityka odgrywa swoją - negatywną - rolę. Słowa: „ja sama..." rozdzielają ideologicznych wrogów na podmiotowe, klasyczne, liryczne „ja" oraz na równie mocno zaakcentowane, ideologicznie obce, zbiorowe „wy”. Poetka chce najpierw pokazać dysproporcje. Można ów przeprowadzony na płaszczyźnie formalnej zabieg określić obrazowo jako "sprawiedliwą samotność" (to świat pierwszoosobowego podmiotu) i świat „tamtych” - lewicowych twórców. Jest ich wielu, ale to właśnie „liryczne” osamotnienie podmiotu, ,ja”, w odróżnieniu od zbiorowego „my”, w imieniu którego Dobrzyński deklaruje swoje „Nie damy...”, buduje postawę heroiczną $\mathrm{w}$ wierszu, a zarazem przewartościowuje konwencję, zmieniając obowiązującą, klasyczną interpretację konstrukcji podmiotu lirycznego. "Ja" nie mówi w swoim tylko imieniu („Czy się głodnemu jeden obiad ziścił od waszych słów? ${ }^{57}$ - przemawia, a raczej ujmuje się za "głodnymi”,

57 Ibidem. 
za proletariatem. Jednocześnie jednak pozostaje klasycznie „liryczne” i samotne w tym agitacyjnym heroizmie. Sznaper rozgrywa klasyczną samotność, ukazuje „szlachetnie osamotnione”, nadaje jednostkowym emocjom znaczenie w walce ideologicznej, co - wobec zbiorowego, jawnie ideologicznego podmiotu wiersza Dobrzyńskiego, który przeciwstawił w Buncie dwie jawnie skonfliktowane grupy - jest pewnym osiągnięciem formalnym, chwytem, jak się wydaje, wzmacniającym przekaz perswazyjny. Sznaper nazywając poetów lewicowych „egoistami”, przenosi konwencjonalny egoizm lirycznego „ja”, z którym publiczność zwykła utożsamiać emocję poetycką, na grupę „wrogów”. To po tamtej, ich, „egoistów”, stronie, zamiast uczuć i emocji „ja”, jest wyłącznie interes i polityka. Poetka „autentyczne” emocje proletariuszy bierze „na siebie”, dzięki czemu głos „ja” czytelnik uzna za szczery i autentyczny, będzie to bowiem głos prosto z - „rozerwanego” dla proletariatu - „narodowego serca”. Obiektywizm, a więc prawdopodobieństwo, które w wierszu ideologicznym często zredukowane zostaje do (obowiązującej, politycznej) prawdy, staje się wyłączną prerogatywą klasycznego „ja”, które może być bardziej emocjonalne od sztampowego zbiorowego „my”. Monopol na prawdę ma tu samotność i emocja, a buduje ją przede wszystkim klasyczna, tj. liryczna konstrukcja indywidualistycznego (nie zaś zbiorowego) podmiotu. „Czerwone słowa” ${ }^{58}$ posiadają obiektywne desygnaty, ale nie mają nic wspólnego z idealizmem, są realne w sposób, w jaki realność rozumie prawica, a nie polityczna lewica: „Nie jesteś mitem czerwieni / ani partyjną larwą [...]"59 - pisze poeta. Narodowcy wiedzą, że uprzedmiotowione idee niechybnie tracą moc. Dla „poetów społeczników” „idea jest [...] tylko pozorem i maską, służącą dla pokrycia brudnych kombinacji jednostek i grup. W ten sposób unika się wszelkiego patosu i wzniosłości, miejsce kompleksów »liryczno-heroicznych «zajmuje cynizm, świnia tryumfująca u podstaw istnienia" ${ }^{60}$. Nic dziwnego, że właśnie pojęcie „materializmu” jak żadne inne, nadaje się wedle Sznaper do literalnego przewartościowania i na taką „rzeczową” dekonspirację zasługuje. Poetka „po prostu” korzysta z antysłownika, demonstrując, jak słabe podstawy ma

\footnotetext{
58 Zob. M. Niżyński, Czerwień marnotrawna, „Prosto z Mostu” 1936, nr 51, s. 5. 59 Ibidem.

60 A. Łaszowski, Literatura tendencyjna, „Prosto z Mostu” 1938, nr 4, s. 7.
} 
samo pojęcie materializmu, ergo - cały system, który w takim ironicznym przypadku trudno w ogóle nazwać ideologią:

z uczonych książek

wybieracie słowa: Rewolucja, Proletariat, Marks, Materializm?!

[...]

i zasypiacie,

i w niebie szukacie,

i na biurku szukacie,

i na własnym krawacie,

Myśląc: żeby było jak najgorsze...,

żeby to czymś przeplatać:

nędzę z buntem pragmatycznie zwiążę!

Parę dat, faktów, historyczny zarys...

No i sława! ${ }^{61}$.

Dobrzyński nie walczy z ideologami, walczy o rząd dusz zagrożonych „politycznością". Do tej krytyki doda więc oryginalne argumenty, przesuwające propagandowość poezji marksistowskiej z agitatorów na agitowanych: wskaże przymus, z jakim „książkowe teorie” są kolportowane oraz zwróci uwagę na bezwzględną obcość materialistycznych idei:

Ej, wy, pisarze co nam w gardziel pchacie

waszą jaźń obcą, chociaż w polskiej szacie -

od waszej strawy popuchły nam gardła,

zakipiał mózg.

Woń waszych przypraw trzewia nam podarła, stanęła w krtani jak dławiąca ość [... $]^{62}$.

Na politykę w wierszu narodowym nie ma miejsca:

ze słowem słabem i cierpliwem, z teorią wyczerpaną aż do zera precz! ${ }^{63}$,

\footnotetext{
${ }^{61}$ S. Sznaper, op. cit.

${ }^{62}$ K. Dobrzyński, op. cit., s. 117.

${ }^{63}$ S. Sznaper, op.cit.
} 


\section{bo, jak podkreślają publicyści oenerowscy:}

Być poetą rewolucji narodowej to nie znaczy pisać wiersze koniecznie programowe, tendencyjne, koniecznie wyraźnie manifestowe. Idealistyczna ideologia narodowa ma właśnie tę wyższość nad każdą inną, a przede wszystkim nad marksizmem, że jej twórczość kulturalna nie potrzebuje parać się $z$ ordynarnie pojętą polityką ${ }^{64}$.

Ideologia, własna nacjonalistyczna opcja, jest tu opowiedziana za pomocą „innego” słowa, całkiem odmiennie organizującego zasady „mówienia ideami”. Narodowy poeta nie postuluje aktywności politycznej - owego politycznego sposobu myślenia, który owocuje równie „politycznym słowem”. Wie bowiem, że słowo to bardzo łatwo zdekonspirować i obnażyć jego

${ }^{64}$ M. Wiśniewicz, List do poety, „Ruch Kulturalny” 1937, nr 4-5, s. 65 . W zasadzie postulat antypolityczności, który rzucają młodzi nacjonaliści, jest oryginalny jedynie wówczas, jeśli pozostaje w kontekście walki ideologicznej. Bardzo ciekawa była pod tym względem również polemika toczona przez najwybitniejszych pisarzy polskiej lewicy (kilkadziesiąt wypowiedzi) na łamach przede wszystkim „Nowego Pisma”. (Zob. np.: J.N. Miller, Jednolity front ludowy a literatura, „Nowe Pismo” 1932, nr 9; K. Irzykowski, O jednolity front w literaturze, „Nowe Pismo” 1932, nr 14; T. Peiper, Stawiam wniosek, „Nowe Pismo” 1933, nr 10). Postulowano w nim hasło walki ideologicznej, a nie partyjnej: „Jednolity front jest koniecznością. Trzeba powoli przygotowywać doń opinię literatów, opinię gór partyjnych, bo masom wszystko jedno, czy Lekkq̨ atletykę napisał Broniewski czy Szymański, ten »socjal-faszysta« [sic!], bo masy potrzebują tych rzeczy, bo w odpowiedzi na gangrenę »Rycerzy Niepokalanej«i »I. K. C.«, na delirium defilad i pielgrzymek, na szał konfiskat procesów i sądów doraźnych musimy odpowiedzieć. Musimy pójść razem, bo tego domaga się od nas sprawa proletariacka" (Zob. E. Szymański, O jednolity front w literaturze, „Nowe Pismo” 1932, nr 11). Atmosferę ideologicznego konfliktu oddawała, wypracowana w ramach tej i innych polemik w obozie lewicy pozornie „wspólna” - bo nie podpisali jej krytykowani przez innych dyskutantów Peiper (za zbyt „szerokie” ujęcie socjalizmu) i Irzykowski (za zbyt liberalne, „klerkowskie” ujęcie) - deklaracja Jednolity front pisarzy („Lewy Tor” 1935, nr 12, s. 3): „Dziś, kiedy reakcja zmusza pisarza do coraz bardziej zdecydowanej służby, nie wolno łudzić się, że w walce dwu światów można zajmować stanowisko neutralne. Rzekoma »aspołeczność« literatury ułatwia tylko faszyzmowi opanowanie życia artystycznego i kulturalnego przy pomocy powoływanych ad hoc instytucji - ułatwia faszyzację kultury". 
nietrwałość i sztuczność. Wtedy „»W dyskusji zasadniczej«bohater zaczyna mówić językiem nieswoim [...], słowom jego brak odpowiedników personalnych, brak po prostu korzenia biologicznego. Są niczyje i puste, choćby

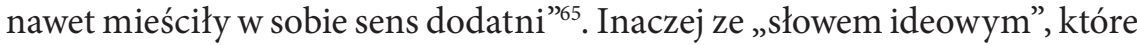
zjawia się jako rezultat twórczego przekształcenia języka i wynik twórczej aktywności podmiotu. W nacjonalizmie mamy do czynienia $\mathrm{z}$ językiem wypowiadającym nie tyle idee polityczne, a emocje podmiotu, jakie owe idee budzą, z przełożeniem polityki na ekspresję. U Wiśniewicza ta opozycja wypowiedziana jest za pomocą metafory przestrzennej (jak widać, również literacka publicystyka korzysta z usług języka poetyckiego): „Marksizm dla literatury to zamknięty pokój, nacjonalizm to nieograniczona przestrzeń życiodajnej i krzepiącej atmosfery"66.

\section{III}

W ten sposób konflikt stawał się dominantą nacjonalistycznej wizji literatury. Nawet przywoływana przez Łaszowskiego tendencyjność okazywała się marksistowskim wynalazkiem, a irracjonalizm narodowy i rzekomy idealizm mogły, jak się zdaje, usprawiedliwiać polityczną grafomanię poetów prawicowych. Tyle tylko, że właśnie pojęcie tendencyjności, wraz ze swoją „idealistyczną” antytezą, w sposób doskonały zanalizowane mniej więcej w tym samym czasie przez Ignacego Fika, kiedy rzeczywiście brane było za element świadomej kultury pisarza i tej estetyki, która nie ucieka od spraw dziejącego się życia - okazywało się niedialektyczną i niemarksistowską koniecznością. Idea i tendencja umożliwiały nie tylko polityczne rozeznanie, ale też oznaczały społeczną świadomość, w której powtarzalnie tendencyjnie wzory spotykały się w wierszu i prozie z praktycznym (społecznym i kulturowym) urządzaniem rzeczywistości, której dopiero forma utworu nadawała idealistyczny bądź praktyczny wymiar. Literatura pośredniczyła w poznaniu - wedle Fika istotną rolę odgrywała tu właśnie tendencyjność: „Tendencja jest siłą. Wprawia w ruch życie. Ma ambicję kierowania jego przemianami. Ruch przez nią wywołany ma kierunek"67.

65 A. Łaszowski, Literatura tendencyjna, „Prosto z Mostu” 1938, nr 4, s. 7.

${ }^{66}$ M. Wiśniewicz, op. cit, s. 65.

${ }^{67}$ I. Fik, Obrona tendencji, [w:] idem, Wybór pism krytycznych, oprac. i wstęp. A. Chruszczyński, Warszawa 1961, s. 51. 
Na uwagę zasługuje tu pojawiające się między wierszami pojęcie polityczności jako celu, wyboru (jednostki, grupy i społecznego) i literatury jako medium eufemizującego politykę, ale - co szczególnie ważne w kontekście wzorów kulturowych (pojęcie „gestu czytelniczego” odzyskuje tu swoją literalność) - immunizujące (jej) radykalizm. To nie polityczność zakłada bierne poddaństwo literatury; ta zaś salwuje się ucieczką w estetykę. To raczej literatura konstruuje (a konstruktywizm społeczny może być, wedle Fika, pozytywną odpowiedzią na tendencję i idealizm ${ }^{68}$ ) własną - zbieżną z tym, co wspólnotowe - polityczność. „Idea i tendencja jest [sic!] rzeczywistością. Jest rzeczywistością ludzką" ${ }^{69}$ - pisze nieco wcześniej, utwierdzając krytyczny (i apologetyczny niemal) wizerunek literatury jako instytucji konstruującej wzory kulturowe i robiącej to lepiej niż wszelka polityka, niż takie jej pojęcia, jak mit i rewolucja.

Słowo narodowe z wiersza Dobrzyńskiego ma być jednak ideałem, zaś jego robotnik, w imieniu którego przemawia - mitem, idealnym „prawdziwym Polakiem", któremu poeta narodowy oddaje lub tylko użycza swego głosu. W tym sensie, w kontekście opisanych wcześniej polemik i sprzeciwów wobec racjonalizmu politycznego, doktryny i partyjnictwa, wiersz jego nie jest polityczny. Zgodnie z logiką radykalnego nacjonalizmu jest antypolityczny, antydoktrynalny, stanowi bowiem dopiero co rozpoczętą perypetię słowa, które należałoby - za Rolandem Barthesem - nazwać słowem mitycznym, skradzionym i oddanym (a raczej przyznanym sobie) ponownie w celu wytworzenia nowej, narodowej, jego perypetii, czyli znaczenia. Prostota pracy symbolicznej, oderwania konkretnego znaczenia od pojęcia, przekształca słowa polityczne w nieupostaciowane, mogące istnieć tylko w propagandzie lub poezji, pisane $\mathrm{z}$ wielkich liter idee. Barthesowski mechanizm odrywania prowadzi do multiplikacji znaczeń mitycznych, ciągłego odradzania się narracji - jak było widać na przykładach - do utrwalania własnego ideologicznego światopoglądu (wraz z jego realną bądź wyimaginowaną, zmanipulowaną Tradycją), a ponadto zrywania więzów z historyczną - w tym także polityczną - rzeczywistością. Nacjonaliści kradną mit robotnika, tym samym wyposażając własną ideologię w nową instancję odbiorczą. Z kolei lewicujący twórcy z lat trzydziestych próbują

68 Zob. ibidem, s. 50.

69 Ibidem, s. 51. 
wypracować ahistoryczny - choć nie mityczny - model literatury, która nie byłaby jedynie powtórzeniem sowieckich haseł budzącego się do życia realizmu socjalistycznego. Albowiem, jak pisał Barthes, „statystycznie rzecz biorąc, mit znajduje się na prawicy. Tam jest dobrze wykarmiony"70, podczas gdy na lewicy - „zupełnie nie istnieje”, lub, jeśli już, to „jest to mit ubogi, ze swej istoty biedny. Nie umie się rozmnażać; wytworzony na zamówienie i czas określony jest źle obmyślony"71 - jest doktryną.

Choć oba, różne z historycznego i politycznego punktu widzenia projekty poezji politycznej dwudziestolecia ${ }^{72}$, dążące do obdarzenia opieką wykluczonych, grzęzną we wzajemnej walce o mit (lewica dąży do jego pozyskania, prawicy wydaje się, że już go zdobyła, potrzebne jest jej tylko znaczenie zapewniające mitowi ponowną perypetię w nacjonalizmie), to wspólnym wrogiem pozostaje sanacyjna władza. To tu właśnie spotykają się rewolucja i mit. Paradoksalnie oba te pojęcia wyzierają z siebie, prowadząc krucjatę przeciwko doktrynie. Wszystkie teksty ujawniały bowiem rewolucyjność i mityczność rozumianą jako sprzeciw wobec formuły i porządku. A jednak wiersze sprzed niemal wieku mówią też o czymś innym. Porządek nie musi być ideologiczny. Jego kulturowe rozumienie może być niepolityczne. Pragnienie obalenia ustroju i rewolucji nie rodzi się przecież między słowami poezji, a jedynie - w szerszym kontekście - angażuje jej formę. Początkowo jest, gdy rzecz uogólnić, połączeniem idealizmu i buntu z romantyzmem rewolucyjnym, lecz wcześniej czy później skutkuje racjonalną i radykalną sugestią przebudowy świata na polityczną modłę. A jednak, jak zauważał Isaiah Berlin, nie jest to cecha oświeceniowego rozumu, XIX-wiecznego późnego realizmu, pragmatyzmu alienującej nowoczesności, budowy, planu i schematu czy też porządku społecznego, który, nieco paradoksalnie, jako interpretację, oddaje literatura i jej instytucja. „Subiektywistyczna etyka romantyzmu zbyt głęboko przeniknęła do świadomości Europejczyków"73, by jedynie poprzedzająca romantyzm, absolutystyczna wizja ancien regime’u mogła

70 R. Barthes, Mitologie, tłum. A. Dziadek, Warszawa 2000, s. 284.

${ }^{71}$ Ibidem, s. 283.

72 Niemniej jednak przede wszystkim nacjonalistyczny, dla którego drugi marksizm - jest antytezą, i, oczywiście, na tej zasadzie - podstawą samookreślenia.

73 I. Berlin, Rewolucja romantyczna: kryzys w historii myśli współczesnej, [w:] idem, Zmyst rzeczywistości, tłum. M. Filipczuk, red. H. Hardy, Poznań 2002, s. 244. 
być odpowiedzialna za wybuch totalistycznych dążeń w wieku XX. Jeśli tak nie jest i rzeczywiście nie możemy wyjść ze schematu wojny kulturowej między rozumem a emocjami, władzą i wolnością, to - po pierwsze - jest to sygnał, że polityczność nadmiernie upomina się o naszą indywidualną i zbiorową uwagę. Po drugie, to również sugestia wyjścia z sytuacji. Możliwością obejścia tragicznej alternatywy, uniknięcia domowej wojny retorycznej, konfrontacyjnej i konfliktującej, jest szeroko rozumiana kultura. Transmisja bezstratna znaczeń nierozmienianych na polityczne intencje (np. dzięki literaturze, która dostarcza nie tylko alternatywy dla znaczeń literalnych, ale też sugeruje możliwość wyboru i może rozbroić narzucającą się i własne cele politykę). Oprócz światów możliwych kultura może tworzyć rzeczywistość mniej chaotyczną niż ta, którą jako pochodną kryzysów chciałaby widzieć polityka. Bowiem:

Autorytet, uzasadnienie, cel - są pojęciami, które pojawiają się w trakcie podejmowania przez jednostki decyzji, by żyć tak lub inaczej; przypisywanie tych decyzji podmiotom zewnętrznym, boskim lub naturalnym, wynika tylko ze słabości, z obawy przed przyznaniem, że my sami jesteśmy odpowiedzialni za to, co robimy w sferze nam przeznaczonej ${ }^{74}$.

Jeśli Eagleton, krytykujący w swej książce formę literatury jako mniej doniosłą niż uważna refleksja i ocena nieetycznych wojen kulturowych, zawoalowanych w antagonistycznej polityczności ${ }^{75}$, ostatecznie przyznaje ważne miejsce formie literackiej, która jako jedna z niewielu daje głęboką i pełną możliwość zrozumienia wszelkich tekstów kultury, bo elementarnym procesem literackości jest uniwersalizacja i konsensualne zrozumienie ${ }^{76}$, to tym prawdziwsze (nie tylko w znaczeniu eskapizmu, jakim dysponuje sztuka, a raczej odwrotnie: niegdysiejszego muru, który burzy ona między

74 Ibidem, s. 243.

75 O antagonistycznej polityce zob. Ch. Mouffe, Agonistyczne przestrzenie publiczne i polityka demokratyczna, http://recyklingidei.pl/mouffe-agonistyczne-przestrzenie-publiczne25 polityka-demokratyczna [dostęp 11.04.2021].

76 Zob. T. Eagleton: op. cit, s. 79. „Tym, co unie możliwia [wyróżnienie - P.K.] spłycającą lekturę tekstu kultury, jest forma estetyczna przekształcająca lokalny materiał w coś zrozumiałego dla szerszego grona odbiorców”. 
porządkami, uniwersalizując idee, zapoznając te niegodziwe i promując te warte namysłu) pozostają słowa Leona Pomiowskiego z 1928 roku:

Sztuka [...] czerpie z życia tzw. świadome dane rzeczywistości i oddaje mu produkt jego podświadomych możliwości. Drogą najściślejszej indywidualizacji stwarza wizję irracjonalnych sprężyn świadomości - a jednocześnie każdą tajemnicę indywidualności usiłuje wyświecić w kategoriach powszechnej świadomości. W tym sensie jest ręką i pulsem istnienia ${ }^{77}$.

Także literatura może być ekwiwalentem pozytywnie ocenianej idei polityki, jednocześnie nie przestając być (jak tego chcieli postmoderniści) narzędziem krytycznym wobec historycznych ideologii - tym porządkiem, który, wprowadziwszy do refleksji pretensje do „zarządzania społeczeństwem", jest symultanicznie dekonspirowany w dziele literackim, nadając refleksji historyczno-literackiej charakter uniwersalizującego i ocennego narzędzia, sytuującego się w „bezczasowej historii idei”. By poznać te idee krytycznie, należy odnieść je (niekoniecznie przenieść i zdublować) do współczesności czytelnika i społeczeństwa. Bo droga do obserwowalnych zachowań politycznych, z której często nie zdajemy sobie sprawy, skądś bierze swój początek. Jest nim - warunkowane np. historią i pamięcią zbiorową, szlakami, którymi podążały dyskusje inicjatorów, ale również ich przodków - narastanie znaczeń, semantycznych możliwości: ich wyboru i oceny. W żadnej innej działalności kulturowej poza literaturą takich możliwości - wolnych wyborów, które nie skutkują, jeśli będą złe, dramatycznymi konsekwencjami, ale również nie są bezkrytycznym wypełnieniem utopii - nie znajdziemy. To oczywiste, że nie należy być z tego specjalnie dumnym: takim powodem do dumy nie jest to, że istnieją nacjonalistyczne i socrealistyczne wiersze, które pozostawiły po sobie ideologie promujące takie hasła, jak: ksenofobia, antysemityzm, niechęć do obcości i inności, które dziś można wypisywać bez żadnych konsekwencji w środkach masowego przekazu i z „błogosławieństwem” nieoczytanej polityki.

77 L. Pomirowski, Doktryna a twórczość, Kraków-Warszawa 1928, s. 81. 


\section{Bibliografia}

[De-ka], Hymn Pracy „Orlęta”, 1930, nr 8.

[Gong], Dla dobra ojczyzny, „Kronika Polski i Świata” 1938, nr 16.

Roland Barthes, Mitologie, tłum. A. Dziadek, Wydawnictwo KR, Warszawa 2000.

Wojciech Bąk, Bałwochwalcom XX wieku, [w:] S. Piasecki, Coraz szerzej..., „Prosto z Mostu"1936, nr 50.

Isaiah Berlin, Zmysł rzeczywistości, tłum. M. Filipczuk, red. H. Hardy, Zysk i S-ka Wydawnictwo, Poznań 2002.

Tadeusz Bujnicki, Bunt żywiołów i logika dziejów, Śląsk, Katowice 1984.

Tadeusz Bujnicki, Trzy poetyki rewolucyjne, b.m.w., 1968.

Kazimierz Czachowski, Z zagadnień osobowości, „Prosto z Mostu”, nr 21.

Roman Dmowski, Myśli nowoczesnego Polaka, wyd. XII popr. i uzup., wstęp N. Tomczyk, Nortom, Poznań 2002.

Adam Doboszyński, Mała encyklopedia pojęć społecznych, M. Fildner \& Sons Publishers, Londyn [1947].

Konstanty Dobrzyński, Czarna poezja, Orędownik, Poznań 1936.

Tadeusz Dworak, Chłopie i robotniku!, „Myśl Narodowa” 1937, nr 10.

Terry Eagleton, Po co nam kultura?, tłum. A. Górny, Warszawskie Wydawnictwo

Literackie Muza, Warszawa 2012.

Henryk Eysymontt, Habitus narodowy (dokończenie), „Myśl Narodowa” 1936, nr 4.

Ignacy Fik, Wybór pism krytycznych, oprac. i wstęp. A. Chruszczyński, Książka

i Wiedza, Warszawa 1961.

Stanisław Gębala, Odpowiedź czerwonemu koledze, „Prosto z Mostu” 1936, nr 11.

Tadeusz Gluziński, Odrodzenie idealizmu politycznego, Dom Książki Polskiej, Warszawa 1935.

W. Gołański, Przewrót, „Orlęta” 1937, nr 1.

Artur Górski, Niepokój naszego czasu, Warszawa 1938.

Władysław Jan Grabski, Poczucie historyczne Polaków, „Ruch Kulturalny” 1937, nr 2.

Jan Grad, Wzory kultury a kształtowanie standardów obywatelskiego myślenia i działania, „Studia Kulturoznawcze” 2017, nr 2.

Aleksander Hertz, Ludzie i idee, Warszawa 1931.

Aleksander Hertz, Socjologia współczesna, Wiedza i Życie, Warszawa 1938.

Karol Irzykowski, O perfidii i szantażu, „Prosto z Mostu” 1935, nr 30.

Aleksander Jałta-Połczyński, Mechaniczny pilot, „Prosto z Mostu” 1936, nr 1.

Karol Ludwik Koniński, Racjonalne - irracjonalne, cz. II, „Myśl Narodowa” 1930, nr 7. Alfred Łaszowski, Literatura tendencyjna, „Prosto z Mostu” 1938, nr 4.

Jan Nepomucen Miller, Jednolity front ludowy a literatura, „Nowe Pismo” 1932, nr 9.

Marian Niżyński, Czerwień marnotrawna, „Prosto z Mostu” 1936, nr 51.

Antoni Peretiatkowicz, Współczesna encyklopedia polityczna, cz. II, s.n., PoznańWarszawa 1926. 
Stanisław Piasecki, Co nas dzieli?, „Prosto z Mostu” 1936, nr 37.

Stanisław Piasecki, Coraz szerzej..., „Prosto z Mostu” 1936, nr 50.

Stanisław Piasecki, Prawo do twórczości, nakładem „Prosto z Mostu”, Warszawa 1936.

Jerzy Pietrkiewicz, Kolorowi ludzie, „Prosto z Mostu” 1936, nr 15-16.

Włodzimierz Pietrzak, O nowoczesną kulturę narodowa, „Młoda Polska” 1937, nr 2.

Ewa Pogonowska, Dzikie biesy. Wizja Rosji Sowieckiej w antybolszewickiej poezji polskiej lat 1918-1932, Wydawnictwo UMCS, Lublin 2002.

Leon Pomirowski, Doktryna a twórczość, Wydawnictwo Jakuba Mortkowicza, KrakówWarszawa 1928.

Witold Pomykaj, Przysięga. Z Poematu o Wielkiej Polsce, „Orlęta” 1938, nr 6.

Stanisław Sapiński, Żagiew paląca, skł. gł. Związek Promienisty, Kraków 1939.

Jan Emil Skiwski, Mania szarzyzny, „Pion” 1936, nr 28.

Janusz Sławiński, Koncepcja języka poetyckiego awangardy krakowskiej, Ossolineum, Wrocław 1965;

Stępień, Wstęp, [w:] Antologia polskiej poezji rewolucyjnej 1918-1939, oprac. M. Stępień, Ossolineum, Wrocław 1982.

Mieczysław Szerer, Śmiertelni bogowie. Rzecz o demokracji i dyktaturze, Rój, Warszawa 1939.

Stanisława Sznaper, Do poetów społeczników, „Prosto z Mostu” 1936, nr 22.

Zygmunt Wasilewski, Listy dziennikarza w sprawie kultury narodowej, Towarzystwo Wydawnicze, Lwów 1908.

Zygmunt Wasilewski, Orientacja wewnętrzna, nakładem „Gazety Polskiej”, Moskwa 1916.

Wojciech Wasiutyński, Nacjonalizm, [w:] idem, Słownik polityczny, Nowy Jork 1980.

Wojciech Wasiutyński, Z duchem czasu, nakładem „Prosto z Mostu”, Warszawa 1936.

Michał Wiśniewicz, Artysta o polityce, [w:] Tworzymy nowy dział, „Ruch Kulturalny” $1937, \mathrm{nr} 2$.

Michał Wiśniewicz, List do poety, „Ruch Kulturalny” 1937, nr 4-5.

Wiesław Zaorski, Walka światopoglądów, „Ruch Młodych” 1936, nr 10-11.

Helena Zaworska, O nowa sztukę, IBL PAN, Warszawa 1963.

Marian Zdziechowski, W obliczu końca, Fronda, Warszawa 1999.

\section{Źródła internetowe}

Alfred Łaszowski, Nacjonalistyczny Człowiek Przełomu, https://www.nacjonalista. pl/2018/08/20/alfred-laszowski-nacjonalistyczny-czlowiek-przelomu/ [dostęp 11.04.2021].

Chantal Mouffe, Agonistyczne przestrzenie publiczne i polityka demokratyczna, http:// recyklingidei.pl/mouffe-agonistyczne-przestrzenie-publiczne25 polityka-demokratyczna [dostęp 11.04.2021]. 


\section{Cultural or Political Civil Wars? The Myth and the Revolution in Pre- war Right-wing Poetry}

The article presents the history of the concepts of myth and revolution in political poetry in the 1930s. Under the pressure of politics, these terms lost their meaning assigned by tradition. This observation leads to conclusions of a more general nature: the essence of involvement and the role of literature as an intermediary between politics as a historical source and politics as a paradoxically non-ideological activity. Thus, literature as an institution mediates in immunizing politics, especially radical politics. Becoming a serious element of the order dictated by the cultural canons existing in equilibrium and their reinterpretations.

Keywords: nationalism, myth, revolution, cultural canon, cultural paradigm

Data otrzymania tekstu: 19.02.2021 r.

Data zakończenia procesu recenzyjnego: 24.03.2021 r.

Data akceptacji tekstu do druku: 31.03.2021 r. 